\title{
Weight parameters of body parts in sika deer (Cervus nippon nippon) from the Konstantinolázeňsko microregion, the Czech Republic
}

\author{
Vladimír Hanzal $^{1,2}$, Klára Košinová1 ${ }^{*}$, Radek Pokorný ${ }^{2}$, Pawel Janiszewski ${ }^{3}$ Vlastimil Hart $^{1}$ \\ ${ }^{1}$ Czech University of Life Sciences, Faculty of Forestry and Wood Sciences, CZ-165 21 Praha 6, Czech Republic \\ ${ }^{2}$ University of South Bohemia in České Budějovice, Faculty of Agriculture, Studentská 1668, CZ-370 05 České Budějovice, \\ Czech Republic \\ ${ }^{3}$ University of Warmia and Mazury in Olsztyn, Faculty of Animal Bioengineering, ul. M. Oczapowskiego 5/366, \\ 10-719 Olsztyn, Poland
}

\begin{abstract}
Sika deer is widely spread species, in Czech Republic mostly occurred in West Bohemia. This species is defined as one of the most harmful ungulate game in the forests. For the wildlife population of sika deer in the microregion Konstantinolázeňsko in West Bohemia, total weight after the hunt, weight after expelling organs, weight of the head and distal parts of the limbs, and weight of the internal organs (heart, lung, liver, spleen, kidney) were determined. Correlations between the weights of specific body parts (organs) were evaluated. Ratio between the weight after expelling organs (after gralloch) and the weight after hunt (total weight) was determined. The weight after expelling organs was $74 \%$ of the total weight. Moreover, a positive correlation was found between the age and weight of individuals, and between the male age and the weight of the head. Without taking into account age differences, we show that males have a higher body weight than females, a form of sexual dimorphism.
\end{abstract}

Key words: sika deer; venision; dressed body weight; organs weight; gralloch, trophy

Editor: Bohdan Konôpka

\section{Introduction}

In recent years, game damage in the Pilsen and Karlovy Vary regions has reached the highest values in the whole Czech Republic. In 2004 the Karlovy Vary region with more than CZK 9 million of damage, the Pilsen region was the third among the regions 2002 with CZK 7.4 million. The highest damage was found in dominant tree species, i.e. in spruce and pine, damage to other trees is negligible in absolute numbers. In the sum of all the trees, the most frequent damage was the reduction of the growth by bark peeling and browseing. High damage to very young spruce stands is probably due to their relatively high surface area, very low yields of honeysuckles and high deer stays. Deers are simply forced to implement their food needs virtually wherever possible (Dvořák \& Čermák 2008).

Game hunting is used as a management technique, for example to control population size and improve population health and quality. It may represent an effective tool for prevention to game damage to forest stands and helps to harmonize interests of both hunting and forestry communities (Konôpka et al. 2015). At the same time, game meat is gaining popularity for human consumption. Game has historically made a certain share of consumed meat for human being. In recent years, some recovery in game meat consumption has been observed. All edible parts of wild game, not only muscle, but also edible intestines, fat, bones and meat products, are considered to be venison. If we process commonly used parts such as intestines, stomachs, pre-jaws, etc. for further consumption, they will also be considered as game (Adámková \& Štochová 2011; Saláková 2014; Winkelmayer 2005).

Sika deer is directly associated with increasing population and can be linked to damaged forest habitat. Sika deer are also a highly adaptable species, which are often hunted for their meat and taken as trophies. The population is increasing, that means also increasing hunting of this species. Sika deer have been documented in the Czech Republic since 1891, when it was brought into Kluk deer-park by Poděbrady (Kokeš 1970; Rakušan 1988).

Introduction of this species into a non-native habitat may change its weight parameters as a part of adaptation to novel environments, such as the type of home range 
resource availability (e.g. food). Dressed-whole body weight relationships should be site- and season-specific to obtain unbiased estimates of whole body weight because of season, geographic variation in morphology, and nutritional state (Jones et al. 2008). For example, roe deer (Capreolus capreolus) in Western Poland shows higher carcass weight in the areas dominated by ploughland compared to areas dominated by forest (Janiszewski et al. 2011).

There are few different studies about sika deer weight in regions across the Czech Republic. In the Bouzovsko region, in the former breeding area of sika deer, the average weight of fawns is $15.3 \mathrm{~kg}$, the average weight of the doe is $26.4 \mathrm{~kg}$, the deer under 4 years weighs on average $39.1 \mathrm{~kg}$, and the average weight of adult deer is $42.7 \mathrm{~kg}$ (Babička et al. 1977). Other sources show, that the male fawns weighed $15.1 \mathrm{~kg}$ and the female fawns were $13.6 \mathrm{~kg}$. Doe aged 1.5 years weigh $20.9 \mathrm{~kg}$, at the age of $2-4$ years weighed $23.8 \mathrm{~kg}$, and deer $>4$ years weighed $26.4 \mathrm{~kg}$. The average weight of spikes was $28.1 \mathrm{~kg}$, deer older than two years weighed $35.2 \mathrm{~kg}$, three years $39.7 \mathrm{~kg}$, four years $42.3 \mathrm{~kg}$, deer under 8 years $45.1 \mathrm{~kg}$, and deer older than 8 years weighed $50.7 \mathrm{~kg}$ (Husák 1986). The weight of the newly born fawn was in the range of $4.7-7 \mathrm{~kg}$ and after half a year they ranged from $25-35 \mathrm{~kg}$. The weight of the gralloched deer is about 40 - 60 kg (Jiřík et al. 1980). The population of sika deer in the district of Pilsen North (weighed after expelling organs, deer without head and doe and fawns with head) shows the average weight of the fawns was $15.7 \mathrm{~kg}$, the average weight of the hind was $23 \mathrm{~kg}$, the four-year-old hinds were $24 \mathrm{~kg}$, and deer older than four-year-olds hind weighed $28 \mathrm{~kg}$. The weight of deer older than eight years is $42.7 \mathrm{~kg}$ (Husák et al. 1986).
In the area of Litovel after World War II two sizes and colour differences in sika deer were described. Larger and darker fawns weighed $16-20 \mathrm{~kg}$, hinds $25-30 \mathrm{~kg}$ and adult headless deer more than $50 \mathrm{~kg}$. The smaller, lighter character is represented by fawns $13 \mathrm{~kg}, 25 \mathrm{~kg}$ hinds weight, deer weighing $40 \mathrm{~kg}$ (Wolf 1999).

In addition, because trophy hunting it is also very important to know the weight of male sika deer head with antlers. Body weight and size, in turn, influenced mineral composition of the antlers of Iberian red deer in Spain (Landete-Castillejos et al. 2007). The weight of the head with antlers is $3.4 \mathrm{~kg}$ that is $6.6 \%$ of the total weight (Husák 1986). Antler weight of pampas deer (Ozotoceros bezoarticus) is increasing with increasing body weight, which is body weight greater in adult males than in males younger than 3 years old (Ungerfeld et al. 2011).

It is also important to understand the difference between the weight of live individual and the weight of individual after expelling organs, i.e. gralloch (Rajský et al. 2013) for the meat production and processing industry. The average weight of the ungralloched fawns from LZ Manětín is $26.4 \mathrm{~kg}$, gralloching weighed $17.5 \mathrm{~kg}$, which is $66.2 \%$ of the original weight. The weight after expelling organs was $66.4 \%$ of total weight. The weight of the deer was $66.1 \%$ versus the ungralloched weight (Husák 1986). Zima (1986) shows a weight loss of $28 \%$ in the fawns, the gralloched body has $72 \%$ of the original weight, the gralloched hind has a $74 \%$ of the weight. The weight of the gralloched body without the head was $65 \%$ of the live weight of the fawns regardless of sex, the hind and the deer had $69 \%$ of the original weight after being gralloch and without the head. Gralloched hinds

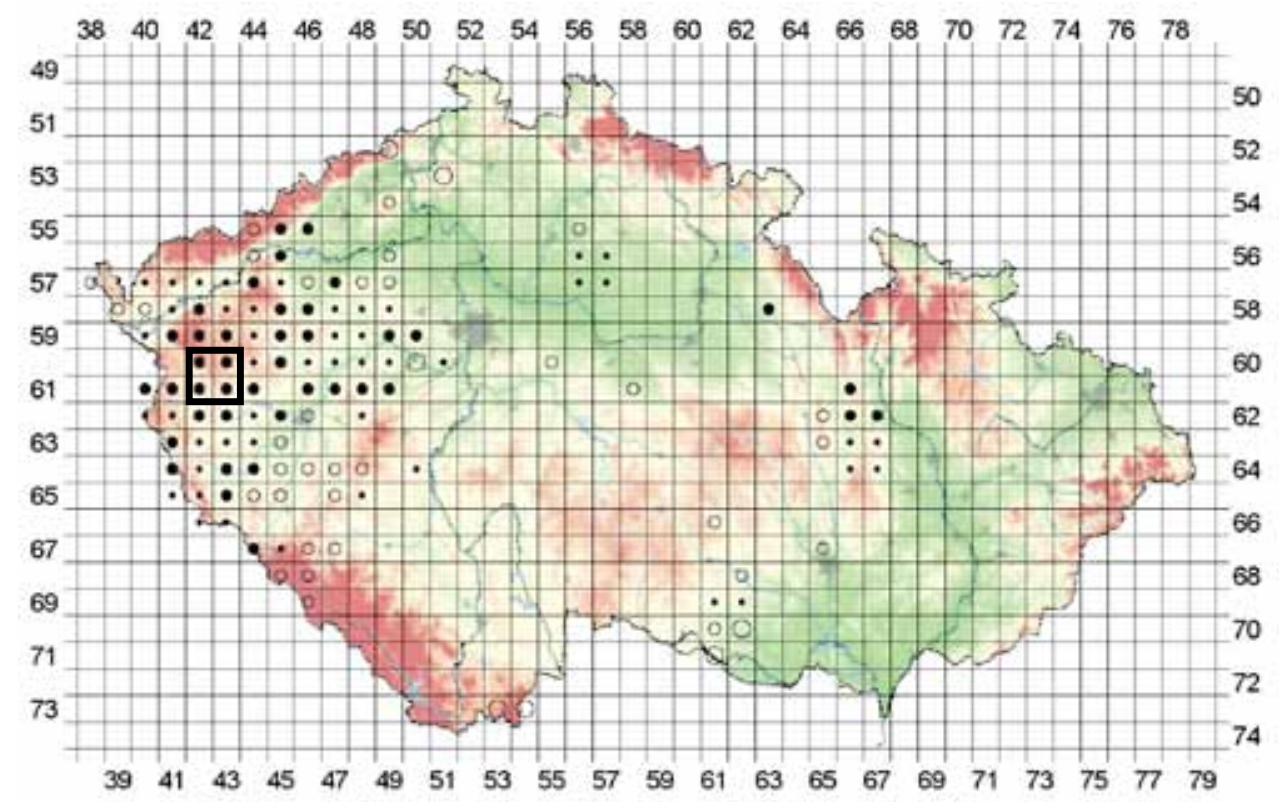

Fig. 1. The extension of the sika deer (Cervus nippon nippon) in the Czech Republic-full colored circle means higher density of occurrence, outlined circle lower density of occurrence (Anděra \& Gaisler 2012). The bold frame indicates the Konstantinolázeňsko microregion. 
in the winter season had $70.2 \%$ of weight before being gralloched, in the summer season was $64.5 \%$ of the total weight of the body. Gralloched deer was found to have a $71.9 \%$ share compared to ungralloched in the winter season, with summer hunting being $71.6 \%$. The difference between the summer and winter seasons of the deer is not statistically conclusive and after rounding the two seasons can be averaged to $72 \%$ (Feldhamer et al. 1984; Husák 1986; Zima 1989).

Most studies deal with comparing the weight and age (Babička et al. 1977; Husák et al. 1986; Hanák 2015; Heroldová \& Zejda 2002; Janiszewski et al. 2009; Jiřík et al. 1980; Mařík 1995; Wolf 1999), sex (e.g. Ježek et al. 2016; Lochman 1993; Hanák 2009) and other parameters but there are no studies about particular weights of the organs. Information about the weight of the organs and each part of sika deer body are still missing and are very important for the game processing.

The body weight of the individual is directly dependent on the food offer. Therefore information about the weight of the individual indicates amount of food needed by the individual animal or the entire population in the given area.

The aim of this study was to document the weight of the game (in particular Cervus nippon nippon) before the shooting, after gralloch and after the game has cooled. Moreover we intended to find the basic differences between these variables, the percentage ratio of the weights, the relationship of these weights and the influence of some aspects on the weight of the individual or the weight of the individual's body parts. Weight dependence on the individual's age as well as weight dependence on the sex were expected.

\section{Material and methods}

In order to obtain the data, 63 individuals of sika deer hunted were weighed. All game was hunted in the northwest edge of the West Bohemia, in the Konstantinoláňsko microregion, Czech Republic, at the border of the Plzeň and Karlovy Vary regions (Fig. 1). Sika deer game were hunted on individual hunts and one common hunt in the 2016/17 hunting season.

Two digital scales were used to obtain weight data, both used simultaneously. The first is the KERN HCN 200K500IP suspension weight with a maximum weighing capacity of $200 \mathrm{~kg}$ and an accuracy of $50 \mathrm{~g}$, this weight was used to weigh the whole pieces hunted before and after the gralloch, and for weighing game after it has cooled down. Second, the Dahongying ACS-40 stationary weight with a maximum weighing of $40 \mathrm{~kg}$ and an accuracy of 5 grams, it was used for the weight of the internal organs, the head, and the distal parts of the limbs. The simultaneous use of both scales was necessary especially for the low accuracy of the weighing instrument, which would not be able to obtain the exact weight of the individual organs while being blocked by the gralloch- ing game. The used stationary weight was also accurate enough to gain the weight of the smaller organs weight (the kidneys, spleen and hearts often did not weigh more than $0.5 \mathrm{~kg}$ ), however, the weighing of whole pieces under $40 \mathrm{~kg}$ was not able (weighing capacity) due to its small loading area.

Internal organs were weighed even if they were damaged by shooting unless they were almost destroyed. Most commonly weighed damaged lungs and liver, the least damaged were the kidneys. Heart weight was recorded without a crust (a blood clot in the heart cavities) and a pericardium. The lungs were weighted without trachea and esophagus. The renal weight is given simultaneously in both kidneys without a protective fat capsule. The spleen was weighed without fat, and no part of the atrophy was visible. Live weight or total weight is the weight of the game after the hunt, including the head and distal parts of the limbs with only loss of part of the blood caused by the shot. The weight after expelling organs (gralloched) is reported after the gralloch, including the head and distal parts of the limbs. Chilled mass is the weight of the gralloched piece without the head and distal parts of the limbs, weighed $12-24$ hours after expelling organs. The weight of legs is the weight of all four legs simultaneously. The weight of the head is also reported for the individuals affected of shoot in it, including the antlers, tongue and the last bite (small brunch). The percentage is calculated from live weight, excluding weight loss by cooling, which is calculated from the weight gralloched after deduction of head mass and legs.

The wild game was gralloch as soon as it was hunted and taken to the place of weighing, except for one deer (found the next day), the game was weighed within 2 hours of its hunt.

After arriving at the weighing area, the hunted game were cut across both Achilles' tendons to place a spacer shall. First, the weight was placed on the hinge of the winch, then the spacer shall was tarred. The game was hung upside down behind Achilles tendon, then pulled up with a winch and weighed to obtain a live weight (excluding only blood lost by the hit). First, the neck was cut off ventrally from the chest to the head (cranial), after that, the thoracic cavity was opened by ca. $3 / 4$, thereby releasing the pressure on the diaphragm and releasing the blood trapped in the chest. Subsequently, the abdominal cavity was opened and the pelvic bone was exposed with a longitudinal section from the rectum to the chest cavity. Cutting the abdominal wall was done with caution and with fingers covered by the tip of the knife to the diaphragm. After the diaphragm was reached, it was cut, reaching the chest cavity. The thoracic cavity was opened by a subsequent cut of the last quarter of the chest. Then, the pelvic bone was cut according to the degree of ossification by the knife or the bone saw, thus opening the pelvic cavity. By small cuts and pulling in the cranial direction, the anal aperture, the rectum, the sexual and secretory organs from the pelvic cavity were released, 
releasing the kidneys, which were cut off and weighed on a stationary scale, then cut and weighed the spleen.

Subsequently, the remainder of the diaphragm was released from the chest, then cut and the liver was weighed. By cutting off the esophagus, the gastrointestinal tract with the defect from the thoracic cavity was separated. After that, the heart was cut off, and it was stripped of the pericardum and the cruor. Followed by the grip of the lungs and by the cranial thrust and the possible cleavage of the lungs, trachea, esophagus and larynx from the chest and neck of the game. A cut was made behind the larynx to separate it from the head. The lungs were cut off from the trachea and then weighed, and the outcast body, including the head and distal parts of the limbs, was weighed. Then the head was cut off between the occipital joint and the atlas, then the head was weighed. The separation of the distal parts of the limbs was performed in the carpal joint at the forelegs and in the tarsal joint at the pelvic limbs.

The age of the game was judged according to the degree of physical development and at the same time according to the degree of development and teeth wear. The game was divided according to body development and the level of denture development on the fawns up to 1 year of age, spikes and hinds up to two years of age and adult individuals.
The data obtained was processed, statistically evaluated and diagrams prepared in MS Excel. An analysis of the correlation of variables was performed. On the basis of the measured values, point charts with the exponential trend line were created, followed by a box-plot.

\section{Results}

The average weight of deer in this study (Table 1.) was $42.0 \mathrm{~kg}$. This average weight includes not only adult individuals but also juveniles with a lower weight. The average weight after expelling organs (gralloch) was $1.2 \mathrm{~kg}$, that is $74 \%$ of the total weight.

We expressed average values partitioned by age class and sex (Table 2). The average weight of the fawn, independent of sex, is $26 \mathrm{~kg}$. Average weight of one year old deer is $45 \mathrm{~kg}$, five year old is $88 \mathrm{~kg}$, suggesting that male deer can gain $43 \mathrm{~kg}$ in four years.

Correlations between sika deer weight and all of the variables were also calculated (Table 3 ). There were several correlations between many of the variables. The strongest (positive) correlation was between total weight, weight after expelling organs, weight of heart and weight of livers. Weight values tend to grow along with increasing age (Fig. 2). There is a statistically significant

Table 1. Average weight values $(\mathrm{kg})$ for sika deer regardless of sex or age $(\mathrm{N}=63)$.

\begin{tabular}{lccccc}
\hline Type of weight & Average & Min & Max & Standard deviation & Coefficient of variance \\
\hline Whole animal & 42.02 & 12.50 & 95.50 & 18.32 & 43.61 \\
After expelling organs & 31.27 & 9.00 & 74.50 & 14.40 & 46.04 \\
After iceing & 26.54 & 7.00 & 61.00 & 12.25 & 46.16 \\
Legs & 1.01 & 0.45 & 1.78 & 0.28 & 27.70 \\
Head & 2.13 & 0.86 & 5.35 & 1.03 & 48.53 \\
Liver & 0.95 & 0.30 & 2.39 & 0.57 & 60.51 \\
Kidneys & 0.14 & 0.04 & 0.60 & 0.10 & 67.85 \\
Lungs & 0.72 & 0.21 & 1.68 & 0.30 & 41.52 \\
Spleen & 0.19 & 0.02 & 0.80 & 0.13 & 70.05 \\
Heart & 0.32 & 0.12 & 0.64 & 0.11 & 34.35 \\
\hline
\end{tabular}

Table 2. Average weight values $(\mathrm{kg})$ for sex and age groups of sika deer.

\begin{tabular}{|c|c|c|c|c|c|c|c|c|c|c|}
\hline \multirow{2}{*}{ Sex and age groups } & \multirow{2}{*}{$\begin{array}{l}\text { Total weight } \\
\text { of individual }\end{array}$} & \multicolumn{9}{|c|}{ Weight } \\
\hline & & after expeling organs & after iceing & of legs & of head & of liver & of kidneys & of lungs & of spleen & \\
\hline Male fawn & 26.19 & 18.96 & 15.96 & 0.81 & 1.41 & 0.51 & 0.08 & 0.52 & 0.10 & 0.23 \\
\hline Female fawn & 26.18 & 19.50 & 16.65 & 0.78 & 1.32 & 0.48 & 0.12 & 0.57 & 0.15 & 0.25 \\
\hline 1-year-old deer & 45.00 & 29.00 & 24.00 & 1.25 & 1.80 & 0.89 & 0.12 & 0.75 & 0.24 & 0.38 \\
\hline 2-year-old deer & 56.67 & 44.67 & 39.24 & 1.24 & 1.62 & 1.13 & 0.37 & 0.69 & 0.24 & 0.41 \\
\hline 3-year-old deer & 60.92 & 44.37 & 38.42 & 1.28 & 2.72 & 1.36 & 0.18 & 0.94 & 0.16 & 0.42 \\
\hline 4-year-old dear & 59.42 & 44.49 & 37.35 & 1.25 & 3.42 & 0.16 & 0.18 & 0.83 & 0.27 & 0.43 \\
\hline 5-year-old dear & 88.25 & 71.00 & 58.50 & 1.66 & 5.16 & 2.35 & 0.24 & 1.50 & 0.37 & 0.57 \\
\hline 1 -year-old doe & 33.83 & 24.17 & 20.50 & 0.87 & 1.68 & 0.66 & 0.12 & 0.67 & 0.17 & 0.25 \\
\hline Older doe & 46.10 & 34.00 & 29.00 & 0.96 & 2.08 & 0.72 & 0.12 & 0.92 & 0.20 & 0.34 \\
\hline
\end{tabular}

Table 3. Correlation of sika deer weights $(\mathrm{kg})$ - gray backgrounds indicate significant correlations at level of $\mathrm{p}<0.05(\mathrm{~N}=53)$.

\begin{tabular}{|c|c|c|c|c|c|c|c|c|c|c|c|c|}
\hline \multirow[b]{2}{*}{ Variable } & \multirow[b]{2}{*}{ Averages } & \multirow[b]{2}{*}{$\begin{array}{l}\text { Standart } \\
\text { deviation }\end{array}$} & \multirow[b]{2}{*}{$\begin{array}{l}\text { Total weight of } \\
\text { the individual }\end{array}$} & \multicolumn{9}{|c|}{ Weight } \\
\hline & & & & $\begin{array}{c}\text { after expeling } \\
\text { organs }\end{array}$ & $\begin{array}{l}\text { after } \\
\text { iceing }\end{array}$ & of legs & of head & of liver & of kidneys & of lungs & of spleen & of heart \\
\hline Total weight of the individual & 43.16 & 18.33 & - & 0.98 & 0.98 & 0.89 & 0.86 & 0.95 & 0.39 & 0.68 & 0.46 & 0.91 \\
\hline Weight after expeling organs & 32.15 & 14.41 & 0.98 & - & 1.00 & 0.89 & 0.86 & 0.93 & 0.41 & 0.67 & 0.45 & 0.91 \\
\hline Weight after iceing & 27.23 & 12.12 & 0.98 & 1.00 & - & 0.88 & 0.83 & 0.92 & 0.42 & 0.66 & 0.45 & 0.90 \\
\hline Weight of legs & 1.04 & 0.27 & 0.89 & 0.89 & 0.88 & - & 0.79 & 0.86 & 0.25 & 0.67 & 0.39 & 0.86 \\
\hline Weight of head & 2.21 & 1.08 & 0.86 & 0.86 & 0.83 & 0.79 & - & 0.88 & 0.23 & 0.67 & 0.39 & 0.77 \\
\hline Weight of liver & 0.97 & 0.59 & 0.95 & 0.93 & 0.92 & 0.86 & 0.88 & - & 0.34 & 0.64 & 0.52 & 0.88 \\
\hline Weight of kidneys & 0.15 & 0.10 & 0.39 & 0.41 & 0.42 & 0.25 & 0.23 & 0.34 & - & 0.19 & 0.15 & 0.30 \\
\hline Weight of lungs & 0.72 & 0.29 & 0.68 & 0.67 & 0.66 & 0.67 & 0.67 & 0.64 & 0.19 & - & 0.27 & 0.61 \\
\hline Weight of spleen & 0.19 & 0.14 & 0.46 & 0.45 & 0.45 & 0.39 & 0.39 & 0.52 & 0.15 & 0.27 & - & 0.48 \\
\hline Weight of heart & 0.33 & 0.11 & 0.91 & 0.91 & 0.90 & 0.86 & 0.77 & 0.88 & 0.30 & 0.61 & 0.48 & - \\
\hline
\end{tabular}




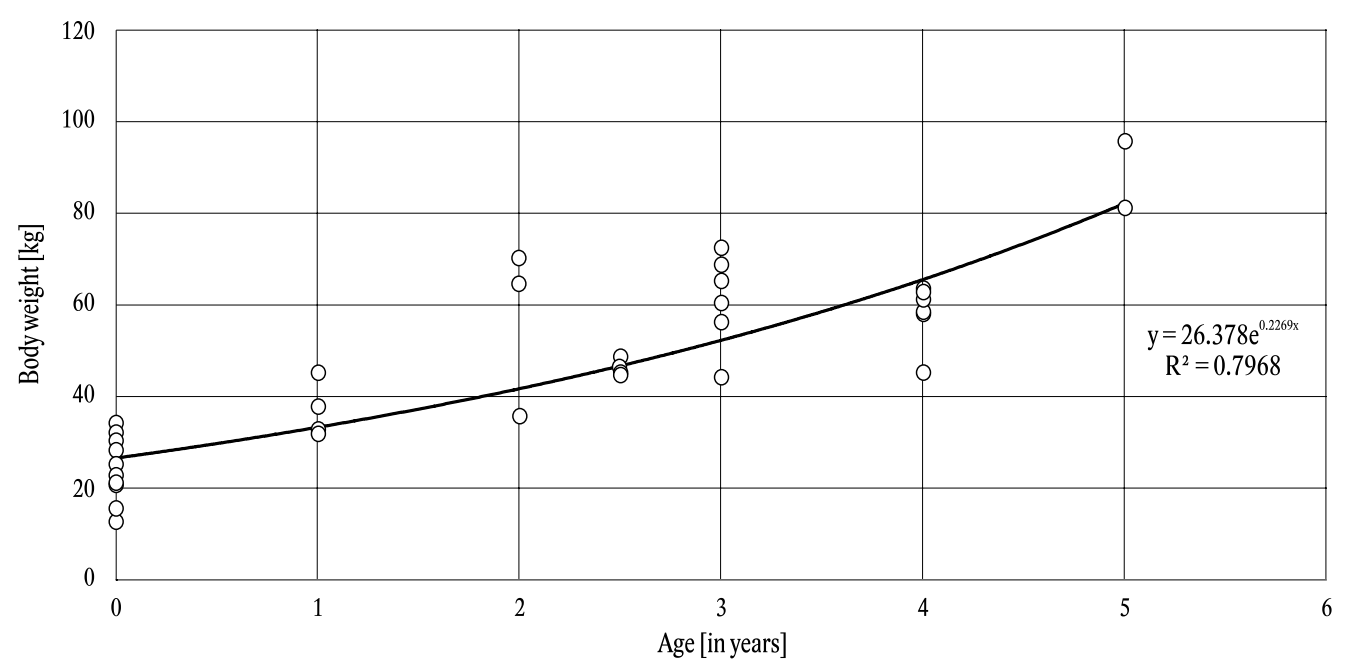

Fig. 2. Influence of age on the weight of sika deer (level of significance $p<0.05$ ). Individual points mean the weight of each individual at a certain age.

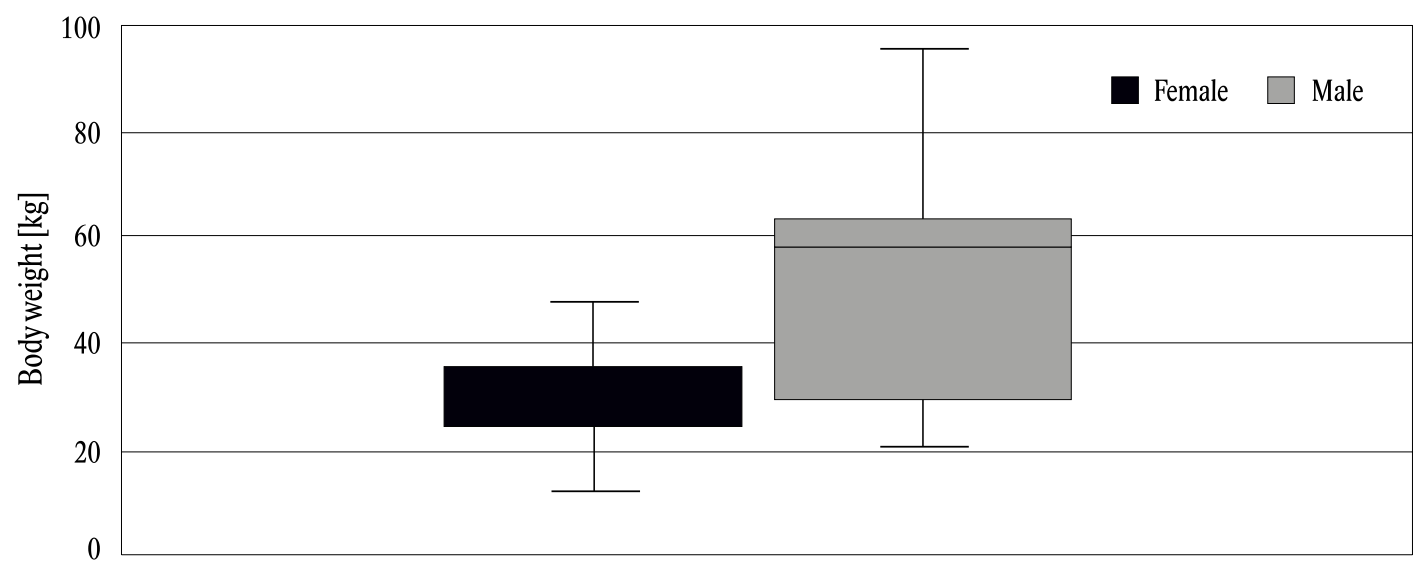

Sex of the individual

Fig 3. Comparison between male and female weights in sika deer. There are weights of the individuals, separated for female and male. The line in the box is median and the average weight is illustrated by the cross in the middle of the box. Maximal and minimal values are illustrated in the segments.

$\left(r^{2}=0.9046\right)$ positive correlation between age and total weight of the individual.

Sex has a significant effect on the weight of individual sika deer (Fig. 3). It is a manifestation of sexual dimorphism, which is evident in this species. Females (does) have an average around $40 \mathrm{~kg}$, males have an average $62 \mathrm{~kg}$, does have around 35\% lower weight than males.

Head weight of male sika deer was affected by age (Fig. 4). In the first year of life the antlers have a lower weight, so it affects the total weight of the head. The head weight is increasing with increasing age, every year about $1 \mathrm{~kg}$ (Fig. 4). Oneyear old deer had an average head weight around $1.5 \mathrm{~kg}$ and in five year old deer the head average head weighted around $5 \mathrm{~kg}$.

\section{Discussion}

The average live weight for all deer combined was 42 $\mathrm{kg}$, similar to the weight reported by Whitehead (1972) showing an average weight of $48 \mathrm{~kg}$. For both measurements, gender and age differences were not taken into consideration, although in these circumstances the difference of $6 \mathrm{~kg}$ can be considered minimal.

The average live weight of fawns, does, and male deer was 26,46 and $61 \mathrm{~kg}$, respectively. The detected average for the fawns is at the lower edge of the range of weights reported by Jiřík et al. (1980) 25-35 kg for half-year olds. However, in this study we measured individuals that were nearly one year of age. The doe and male deer almost coincide with Lochman (1993), giving a live weight of $45 \mathrm{~kg}$ 


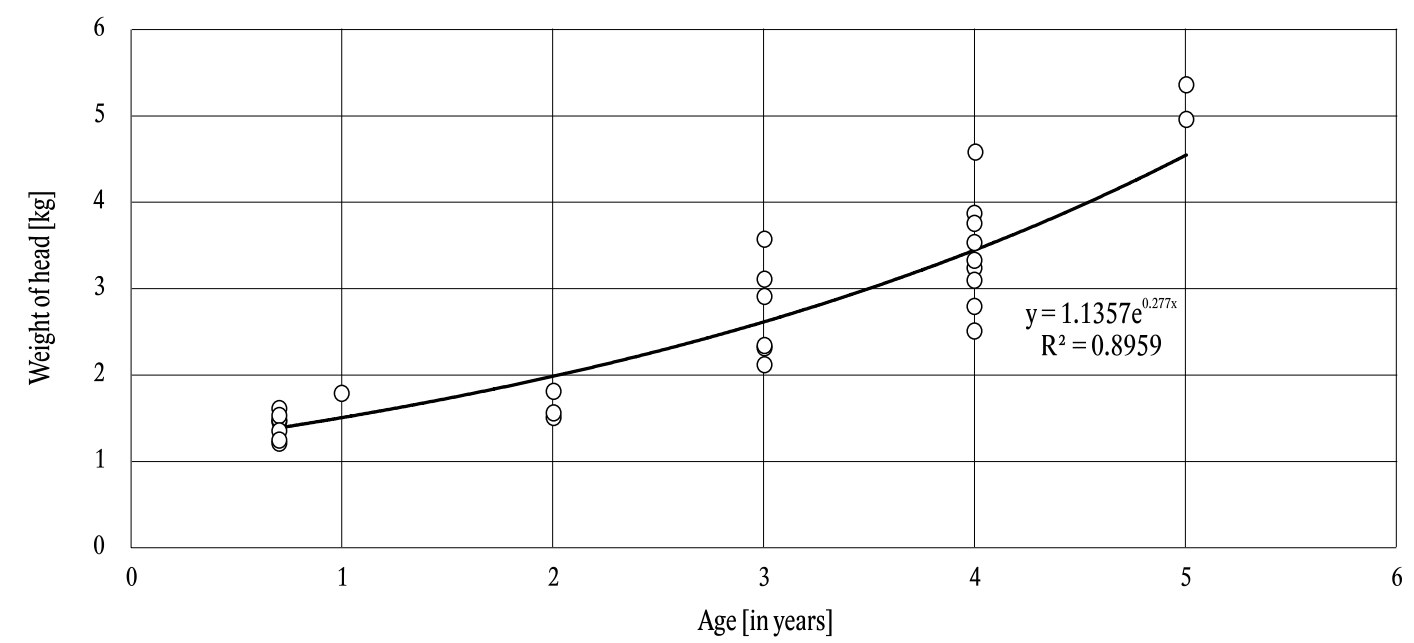

Fig. 4. Influence of age male sika deer on head weight (level of significance $p<0.05$ ). Individual points mean the weight of the head of each individual at a certain age.

and deer $55 \mathrm{~kg}$. Ohdachi (2010) reports the live weights of deer and deer in the original Japanese homeland of $25-80 \mathrm{~kg}$ and $50-130 \mathrm{~kg}$ in deer, which corresponds to the data found in the work by Lochman (1993).

The average gralloched weight of fawns found in this study is $19.3 \mathrm{~kg}$, which is a higher weight than Babička et al. (1997) $15.3 \mathrm{~kg}$, Husák et al. (1986) in the district of Pilsen north $15.7 \mathrm{~kg}$, and Bouzovsko $13-15 \mathrm{~kg}$, smaller type of sika deer by Wolf (1999) weighed $13 \mathrm{~kg}$, Uckermann (1972) in the regions Hochrheingebiet $17.6 \mathrm{~kg}$ and Arnsberg $15.8 \mathrm{~kg}$ and Feldhamer et al (1984) 13.2 $15.4 \mathrm{~kg}$. Lower weight can be justified by weighing pieces after iceing possibly without heads and legs, which are often not specified by the authors. In this study, the mean weight was also determined without head and legs and after iceing (16.4 kg), more similar to the stated weights. An alternative possibility of higher weight is the current hunting of older fawns after $15^{\text {th }}$ January, which is only allowed after 2014. Similar weights as published in this study by Ueckermann (1972) for Ostangeln fawns $20 \mathrm{~kg}$, Wolf (1999) 16 - $20 \mathrm{~kg}$ and Ježek et al. (2016), weighing $18.2 \mathrm{~kg}$. These weights are almost identical and confirm the weight found in this study.

The gralloched weight of does was $34 \mathrm{~kg}$, which is comparable to Ježek et al. (2016), which reported a weight of $30.6 \mathrm{~kg}$, but does not indicate how game was weighed. It is probable that the weight is in the purchase state, with an average purchase weight of $29 \mathrm{~kg}$. This weight is even more similar to the weights of Ježek et al. (2016) for the Kladská region of $28.8 \mathrm{~kg}$ and the Manětín area, where for 5 year olds, the weight was $29 \mathrm{~kg}$. The weight of Manětín sika deer is identical to this study, and the value of Kladská is lower by $0.2 \mathrm{~kg}$. This can be explained by the location of the area tested in this work between Kladska and Manětín, a population with similar living conditions and probable genetic similarity. Another comparable weight of hinds is given by Wolf (1999) in the
Greater Siege of Litovelsko. It lists the weight of the hind $25-30 \mathrm{~kg}$. The other authors Babička (1977), Husák et al., 1986, Feldhamer et al. (1984), Uckermann (1972) report a lower weight of approximately $10 \mathrm{~kg}$ compared to the gralloched weight in this study, and it can be argued that the milder winters in recent years, the inclusion of the Dybowski subspecies into the current genotype, and/ or better adaptation (already "domesticated" game) to the conditions of the local environment can account for this difference.

The average weight of the deer without age difference was $46.7 \mathrm{~kg}$. This weight is between $40 \mathrm{~kg}$ and $50 \mathrm{~kg}$ of Litovel's sika described by Wolf (1999), also corresponds to the weight of $40-60 \mathrm{~kg}$, reported by Jiřík et al. (1980), 35 - $55 \mathrm{~kg}$, reported by Hanák (2015) and weight 33 $78 \mathrm{~kg}$ by Heroldová \& Zejda (2002), which is similar to the minimum and maximum values found in this work of $28-74.5 \mathrm{~kg}$. The slightly lower values compared to this work indicate for the various age categories Babička et al. (1977) and Husák et al. (1986). Uckermann (1972) and Feldhamer et al. (1984), whose average weights are approximately $10 \mathrm{~kg}$ lower, the largest reported differences compared to other studies. This difference of about $20 \%$ may be due to different natural conditions or a genetic basis, since Feldhamer et al. (1984) weighed sika from the USA and Feldhamer et al. (1984) weighed German deer.

It is generally know, that the weight of the individual is decreasing in higher age. The average weight of hinds aged $1-2$ years is $26 \mathrm{~kg}$, the mean weight at the age of 3 -4 years is $30.9 \mathrm{~kg}, 5-6$ years old is $34 \mathrm{~kg}$ and in the case of 6 years old or more, the average weight drops to 31.6 $\mathrm{kg}$. The average weight of the hinds without age and area difference is $30.6 \mathrm{~kg}$. (Hanák 2015; Heroldová \& Zejda 2002; Husák et al. 1986; Jiř́k et al. 980; Wolf 1999). The Moravian population of sika deer weighed gralloched with the head (Heroldová \& Zejda 2002) and determined 
weights of hinds ranged from $19-50 \mathrm{~kg}$ and deer have a total weight $33-78 \mathrm{~kg}$. The height growth potential is more observed in the first month of life. Red deer male fawn in Hungary has already at 182 days of age $75.8 \mathrm{~kg}$ and female fawn $65.6 \mathrm{~kg}$ of live weight (Julianna et al. 2015).

Yokoyama et al. (2001) present that there is correlation between kidney mass and body mass 0.9 . Results of this study are not consistent with the result of our study. Correlation between total weight and weight of the kidney is only 0.4 at level of significance $p<0.05$. That mean, that there was not significant dependency between these two variables.

The percentage of weight of the gralloched bodies compared to the total weight was $73.6 \%$ for the fawns, $73.8 \%$ for the does, $75.4 \%$ for the male deer and for $74 \%$ for all individuals without age and gender differentiation. The values found here are closest to Zima (1986), 72\% for fawns, $74 \%$ for does and $75 \%$ for deer, the values for does and deer are the same, with a slight difference of $1.6 \%$ for fawns. Feldhamer et al. (1984) shows values for hind and deer with a difference of up to $3.5 \%$, for the doe is 70 , $2 \%$ and for deer $71.9 \%$. Husák (1986) values, $66.2 \%$ for fawns, $66.5 \%$ for does and $66.1 \%$ for deer. The difference in deer is close to $10 \%$, the lower percentage difference is for fawns and does about 7,3\%. A possible reason for such high differences can be the weight gain procedure that Husak et al. (1986) doesn't explain, it is possible that the gralloched bodies are weighted only after iceing, the percentage of which in this work is $5.8 \%(0.5-11.9 \mathrm{~kg})$.

\section{Conclusion}

Our study conducted in the microregion of Konstantinolázeňsko showed that the average total weight of sitka deer was $42 \mathrm{~kg}$. The gralloched weight was $74 \%$ of the total weight after hunt. There was a correlation between the total weight and age - with the increasing age isalso increasing the weight of the individual. Results show sexual dimorphism of sika deer. Females (does) have an average around $40 \mathrm{~kg}$, male (deer) have an average of 62 $\mathrm{kg}$, does have around $35 \%$ lower weight than deer. There was also influence of age on the weight of head, which is increasing with higher age. Antlers are progressing throughout life, and in the first years of the life antlers grow faster. Five years old deer have the heaviest head, which also reflects the weight of the antlers. The correlation between the total (live) weight and other weights was significant $(\mathrm{p}<0.05)$ for the weight of the liver and heart.

\section{Acknowledgement}

Dr. Michael Scott Painter is acknowledged for English language revision of the manuscript.

\section{References}

Adámková, V., Štochová, J., 2011: Zvěřina pro zdraví. České Budějovice. Jihočeská univerzita v Českých Budějovicích, 200 p.

Anděra, M., Gaisler, J., 2012: Savci České republiky: popis, rozšíření, ekologie, ochrana. Praha, Academia, $285 \mathrm{p}$.

Babička, C., Drábek, M., Štika, J., Ženožička, J., 1977: Poznatky z chovu jelena siky. Myslivost, 11:270-271.

Dvořák, J., Čermák, P., 2008: Jelen sika - škody ve vybraných honitbách Plzeňska. Kostelec nad Černými lesy. Lesnická práce, 87:12-14.

Feldhamer, G. A., Stauffer, J. R., Chapman, J. A., 1984: Body morphology and weight relationships of sika deer in Maryland. Zeitschrift für Säugetierkunde 50:88-106.

Hanák, J., 2015: Jelen sika japonský: životní způsob, chov, jak dobře vábit a účinně lovit. Praha, Arista Books, $100 \mathrm{p}$.

Heroldová, M., Zejda, J., 2002: Body dimensions and coloration of the winter pelage of a Moravian population of sika deer, Cervus nippon. Folia Zoologica, 51:253-256.

Husák, F., Wolf, R., Lochman, J., 1986: Daněk (sika) jelenec. Praha, SZN, 320 p.

Janiszewski, P., Daszkiewicz, T., Hanzal,V., 2009:Wpływ czynników przyrodniczych i terminu odstrzału na masę tuszy sarny europejskiej (Capreolus capreolus L.). Leśne Prace Badawcze, 70:123-130.

Janiszewski, P., Gugolek, A., Hanzal, V., Bólkowski, D., 2011: Variability of the Carcass Weight of the Red Deer (Cervus elaphus L.) in Poland. Polish Journal of Natural Sciences, 26:99-110.

Ježek, M., Holá, M., Kušta, T., Hart, V., Červěný, J., 2016: Reprodukční charakteristiky samic jelena siky: výzkumné projekty Grantové služby LČR. Praha, Lesy České republiky, s. p., Edice Grantové služby LČR, $43 \mathrm{p}$.

Jiřík, K., Anděra, M., Mottl, S., 1980: Atlas zvěře. Praha: SZN, 256 p.

Jones, R. L., Weckerly, F.W., McCullough, D.R., 2008: Influence of age and sex on dressed-whole body weight relationships in black-tailed deer. California Fish and Game, 94:137-142.

Julianna, B., János, N., István, N., Miklós, S., András, S., Árpád, B., Péter, H., 2015: Examination and modelling of growth of Central European red deer (Cervus elaphus hippelaphus) from birth until 7-8 month of age. Magyar Allatorvosok Lapja, 137:633-640.

Kokeš, O., 1970: Asijští jeleni na území Československa. Ochrana fauny, 4:158-161.

Konôpka, J., Kaštier, P., Konôpka, B., 2015: Teoretické východiská a praktické opatrenia na harmonizáciu záujmov lesného hospodárstva a pol'ovníctva na Slovensku. Lesnícky časopis - Forestry Journal, 61:114-123. 
Landete-Castillejos, T., Garcia, A., Gallego, L., 2007: Body weight, early growth and antler size influence antler bone mineral composition of Iberian Red Deer (Cervus elaphus hispanicus) Bone, 40:230-235.

Lochman, J., Hanzal, V., Liebl, F., 1993: Myslivost v obrazech: zoologie. 2. Praha: ČMMJ, 102 p.

Mařík, Z., 1995: Kraniometrie a hmotnosti těla jelenců viržinských (Odocoileus virginianus Zim.) ulovených v České republice v oblasti Dobříše. Folia venatoria, 25:51-58.

Ohdachi, S., 2009: The wild mammals of Japan. Kyoto: Shoukadoh Book Sellers, 544 p.

Rajský, M., Rajský, D., Minárik, M., 2013: Kol'ko váži? Výpočet živej hmotnosti raticovej zveri. Lovu zdar!, 5:44-46.

Rakušan, C., 1988: Základy myslivosti. Praha, SZN, $412 \mathrm{p}$.

Saláková, A., 2014: Hygiena a technologie drůbeže, vajec a zvěřiny. Brno, Veterinární a farmaceutická univerzita, $80 \mathrm{p}$.

Ueckermann, E., 1972: Das Sikawild in der Bundesrepublik. Der deutsche Jagër, 29:235-239.
Ungerfeld, R., Villagrán, M., González-Pensado, S., 2011: Antler weight and body weight relationship in adult and young pampas deer (Ozotoceros bezoarticus) males, North-Western Journal of Zoology, 7:208-212.

Whitehead, G. K., 1972: Deer od the World. Constable, London, 194 p.

Winkelmayer, R., Lebersorger, P., Zedka, H., 2005: Hygiena zvěřiny. Př́ručka pro mysliveckou praxi. Institut ekologie zvěře VFU Brno, 168 p.

Wolf, R., 1999: Historie chovu jelena siky na území České republiky. In: Introdukovaná spárkatá zvěř '99 současná a budoucí chovatelská problematika, sborník referátů, Dobříš 20.-21. srpna 1999. Praha, Česká lesnická společnost, p. 52-56.

Yokoyama, M., Onuma, M., Suzuki, M., Kaji, K., 2001: Seasonal fluctuations of body condition in northern sika deer on Hokkaido Island, Japan. Acta Theriologica, 46:419-428.

Zima, J., 1989: Biologie lovné zvěře: vybrané výsledky z řešení kontrolovatelné etapy hlavního úkolu SPVZ č. VI-1-6 Základní předpoklady optimalizace hospodaření s některými druhy lovné zvěře za období 1986 - 1989. Brno, Ústav systematické a ekologické biologie ČSAV. 